\title{
A new species of marine algae from Korea based on morphology and molecular data: Gelidium palmatum sp. nov. (Gelidiales, Rho- dophyta)
}

\author{
Ga Hun Boo ${ }^{1,2, *}$ and Kyeong Mi Kim ${ }^{3}$ \\ ${ }^{1}$ Department of Biological Sciences, Chungnam National University, Daejeon 34134, Korea \\ ${ }^{2}$ Núcleo de Pesquisa em Ficologia, Instituto de Botânica, São Paulo 04301-902, Brazil \\ ${ }^{3}$ Department of Taxonomy, National Marine Biodiversity Institute of Korea, Seocheon 33662, Korea
}

Two species of the agar-yielding genus Gelidium, G. galapagense and G. isabelae, have previously been reported from Korea but their occurrence has not been confirmed with molecular data. We intensively collected samples of Gelidium from Jeju Island, where the two species were reported, and the southern coast of Korea. Phylogenetic analyses based on $c o x 1$ and $r b c \mathrm{~L}$ sequences revealed that only a single species occurred in Korea. The Korean species was distantly related to G. galapagense and G. isabelae from the Galápagos Islands, and formed a clade with G. microdonticum, G. millarianum, and G. pakistanicum. A new species, G. palmatum, is described for those specimens that were previously recognized as either G. galapagense or G. isabelae from Korea. G. palmatum is small in size (up to $0.7 \mathrm{~cm}$ ), with compressed, lanceolate axes, irregular, digitate to palmate branches, abundant rhizines in the medulla, tetrasporangial sori without sterile margins, and rounded bilocular cystocarps borne subapically on palmate branchlets.

Key Words: agar-yielding algae; coxl; Gelidium galapagense; Gelidium isabelae; morphology; phylogeny; rbcL; systematics

\section{INTRODUCTION}

Gelidium, the most speciose genus in the order Gelidiales, comprises 145 species that are found worldwide in intertidal and subtidal zones of cold-temperate to tropical coasts (Freshwater and Rueness 1994, Boo et al. 2014, Guiry and Guiry 2019). This genus is a unique marine source for agarose gel for molecular work, and agar, a medium for microbiological studies; rhizine fibers are harvested for the industrial development of nanocomposites (Callaway 2015, Chen et al. 2016).

Small-sized Gelidium species are so simple in morphology that DNA analysis is needed for the correct identification. Molecular studies have shown that widespread species actually comprise hidden local species, or that geographically isolated local species turned out a single widespread species. For example, G. crinale (Hare ex Turner) Gaillon was confirmed to be a cosmopolitan species distributed throughout the Atlantic and Pacific waters, while G. pusillum (Stackhouse) Le Jolis is endemic to the north Atlantic (Freshwater and Rueness 1994, Millar and Freshwater 2005, Kim and Boo 2012).

Sohn and Kang (1978) were the first to study Gelidium from Korea, reporting nine species, and Lee (1988) studied the morphology of six species from Jeju Island. Lee (1994) and Lee and Kim (1995) provided descriptions of
(9) This is an Open Access article distributed under the terms of the Creative Commons Attribution Non-Commercial License (http://creativecommons.org/licenses/by-nc/3.0/) which permits unrestricted non-commercial use, distribution, and reproduction in any medium, provided the original work is properly cited.
Received December 11, 2019, Accepted March 6, 2020

* Corresponding Author

E-mail: gahunboo@gmail.com

Tel: +82-42-821-5491, Fax: +82-42-822-9690 
eight species with a key to enable species identification. Lee et al. (2005) first reported the occurrence of G. galapagense W. R. Taylor at Geumneung, Jeju Island. Kim and Hwang (2015) reported 17 species of Gelidium including G. isabelae W. R. Taylor from Jeju Island. Recent molecular studies have revealed many new species of Gelidium from Korea. Kim et al. $(2011,2012)$ described five new species, G. coreanum K. M. Kim, J. K. Park, I. K. Hwang, H. S. Yoon \& S. M. Boo, G. eucorneum K. M. Kim, J. K. Park, I. K. Hwang \& S. M. Boo, G. jejuense K. M. Kim, J. K. Park, I. K. Hwang, H. S. Yoon \& S. M. Boo, G. minimum K. M. Kim, J. K. Park, I. K. Hwang, H. S. Yoon \& S. M. Boo, and G. prostratum K. M. Kim, J. K. Park, I. K. Hwang, H. S. Yoon \& S. M. Boo. Boo et al. (2014) confirmed the occurrence of G. johnstonii Setchell \& N. L. Gardner, which was considered as misidentified in Korea, and Boo et al. (2016b) added G. longiramulosum (Y. P. Lee \& B. S. Kim) G. H. Boo and G. yoshidae G. H. Boo \& R. Terada, which were previously attributed to the genus Acanthopeltis. On the other hand, Boo et al. (2013) transferred G. divaricatum G. Martens to the genus Gelidiophycus.

Reports of G. galapagense and G. isabelae from Korea have been questionable because of their simple and homoplastic morphologies. Lee et al. (2005) recognized Korean G. galapagense on the basis of characteristics of tetrasporangial stichidia, which arise on fan- or digitate tips of branches with short pedicels. This species has been included in seaweed floras of Korea (Lee 2008, Kim and Hwang 2015). However, Boo et al. (2016a) reported that Korean G. galapagense was very close to G. millarianum G. H. Boo, Hughey, K. A. Miller \& S. M. Boo from Australia and might be assigned as a new species. Kim and Hwang (2015) proposed that G. isabelae from Korea was previously misapplied as G. pusillum by Lee (1988) and G. pusillum var. pacificum W. R. Taylor by Lee and Kim (1995). Korean G. isabelae was recognized on the basis of the visible decussate lines by resulting of uneven thickness of the pigmented cortical cell layer in the flattened, distal portions of erect branches. However, recent analysis of mitogenomes from type specimens of G. galapagense and G. isabelae raised questions about reports of these two species outside the Galápagos Islands (Boo et al. 2016a).

The objectives of this study were to investigate the occurrence of G. galapagense and G. isabelae in Korea and to provide a phylogeny to clarify the identities of Korean species. We intensively collected specimens that were morphologically similar to the descriptions of Korean $G$. galapagense and G. isabelae provided by Lee et al. (2005), Lee (2008) and Kim and Hwang (2015). We analyzed two molecular markers, mitochondrial $c o x 1$ and plastid $r b c \mathrm{~L}$, from specimens for which we observed the anatomy and morphology. On the basis of morphological features and phylogenetic relationships, we recognize a new species of Gelidium from Korea.

\section{MATERIALS AND METHODS}

Specimens were collected in the intertidal zone at Goheung and Wando on the southern coast of Korea, and at Jeju Island (Supplementary Table S1). They were mounted on herbarium sheets and subsamples were dehydrated in silica gels for DNA sequencing. For anatomical observation, plants were sectioned using razor blades and were stained with $1 \%$ aqueous aniline blue. Photographs were taken with a DP-71 camera (Olympus, Tokyo, Japan) mounted on a BX-51 microscope (Olympus). Holotype, isotype and paratype specimens are housed at the Herbarium of the Department of Biology, Chungnam National University, Daejeon, Korea (CNUK) (Thiers 2019).

DNA extraction, polymerase chain reaction amplification, and sequencing were performed as described in Boo et al. (2013). The primers used for amplifying and sequencing were F7, F645, R753, and RrbcS start for $r b c \mathrm{~L}$ (Freshwater and Rueness 1994, Lin et al. 2001, Gavio and Fredericq 2002), and COXI43F and COXI1549R for cox1 (Geraldino et al. 2006). Sequences of the forward and reverse strands were determined for all taxa, and the electropherograms were edited using MEGA7 (Kumar et al. 2016) and checked manually. Newly generated sequences were deposited in GenBank. Sequences were aligned using the MUSCLE algorithm in MEGA7 with default parameters and the alignment was manually adjusted. Three outgroup species representing three other genera in the Gelidiaceae (Boo et al. 2016b), Capreolia implexa Guiry \& Womersley, Gelidiophycus freshwateri G. H. Boo, J. K. Park \& S. M. Boo, and Ptilophora spongiophila G. H. Boo, L. Le Gall, I. K. Hwang, K. A. Miller \& S. M. Boo, were included in the alignment.

Phylogenies of coxl and $r b c \mathrm{~L}$ datasets were reconstructed using maximum likelihood (ML) and bayesian inference (BI). The best-fitting nucleotide substitution model was selected using jModelTest v2.1.10 (Darriba et al. 2012) with Akaike Information Criteria. The ML analyses were performed using the Pthreads version of RAxML v8.0.X (Stamatakis 2014) set as follows: a rapid bootstrap analysis and search for the best-scoring ML tree in one single program run with 1,000 bootstrap replicates under GTR + G + I model. The BI analyses were performed for 


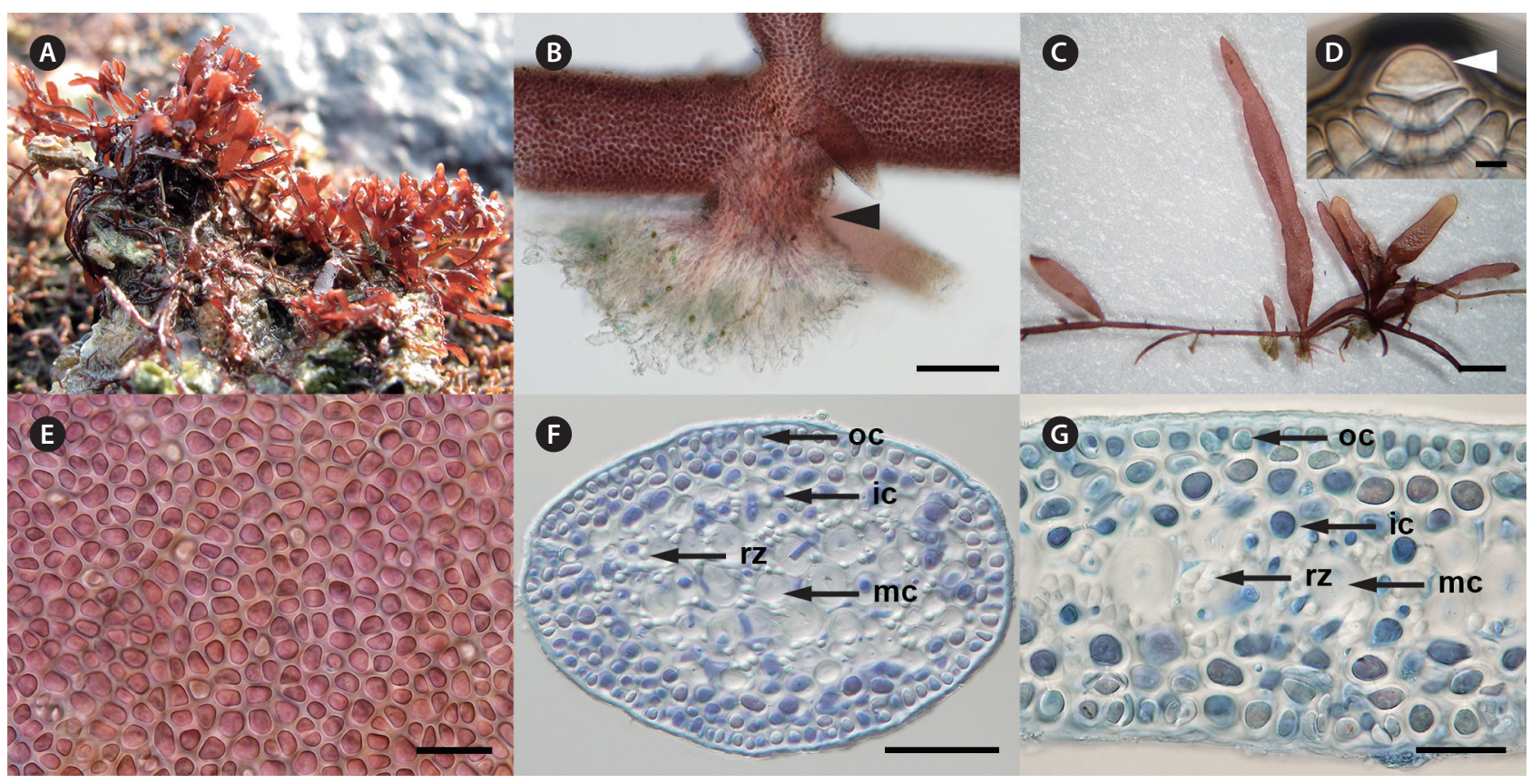

Fig. 1. Vegetative structure of Gelidium palmatum sp. nov. (A) Plants growing on rock in the intertidal zone at Donggori, Wando, Korea on Jul 14, 2014. (B) A brush-like hapteron (arrowhead) (CNU059012). (C) Simple branching pattern of vegetative thallus (CNU059012). (D) A dome-shaped apical cell at the tip of a branchlet (arrowhead) (CNU059022). (E) Surface view of outermost cortical cells showing their irregular arrangement (CNU059022). (F) Transverse section of a terete prostrate stolon showing outermost cortical cells (oc), inner cortical cells (ic), rhizines ( $\mathrm{rz}$ ), and medullary cells (mc) (CNU059012). (G) Transverse section of flattened erect axis showing outermost cortical cells (oc), inner cortical cells (ic), rhizines (rz), and medullary cells (mc) (CNU059012). Scale bars represent: B, $100 \mu \mathrm{m} ; \mathrm{C}, 1 \mathrm{~mm} ; \mathrm{D}, 5 \mu \mathrm{m} ; \mathrm{E} \& \mathrm{G}, 20 \mu \mathrm{m} ; \mathrm{F}, 50 \mu \mathrm{m}$. [Colour figure can be viewed at http://www.e-algae.org].

individual datasets with MrBayes v.3.2.1 (Ronquist et al. 2012) using the Metropolis-coupled Markov Chain Monte Carlo (MC3) with the GTR + G + I model. For each matrix, four million generations of two independent runs were performed with four chains and sampling trees every 100 generations. The burn-in period was identified graphically by tracking the likelihoods at each generation to determine whether they reached a plateau. Twenty-five percent of saved trees were removed, and the remaining trees were used to infer Bayesian posterior probabilities (BPP).

\section{RESULTS}

\section{Gelidium palmatum G. H. Boo \& K. M. Kim sp. nov. (Figs 1 \& 2)}

Description. Thallus light to dark red, up to $0.7 \mathrm{~cm}$ high, forming a turf on upper intertidal rocks (Fig. 1A), with terete prostrate branches attached by brush-like holdfasts (Fig. 1B). Erect branches cylindrical at base, becoming compressed, 0.1-0.3 $\mathrm{mm}$ in width, lanceolate to clavate (Fig. 1C), with longitudinal striations. Apices mostly obtuse with a prominent apical cell (Fig. 1D); surface cells rounded, arranged irregularly (Fig. 1E); cortex consisting of 3-5 layers in prostrate portions (Fig. 1F), 3-4 layers of globose to elliptical cells in compressed branches (Fig. 1G); rhizines abundant in medulla (Fig. 1F \& G). Tetrasporangial sori without sterile margins arising on ultimate branchlets, tetrasporangia irregularly arranged (Fig. 2A), up to $12-34 \times 33-61 \mu \mathrm{m}$ (Fig. 2B). Spermatangia in terminal sori on strongly compressed branchlets with rounded apices (Fig. 2C \& D). Cystocarps 310-450 $\mu \mathrm{m}$ in diameter, spherical to ovoid on subapical parts of palmate branches, bilocular (Fig. 2E \& F), with one ostiole on each surface.

Holotype. CNU059012, Jul 14, 2014, G. H. Boo, a tetrasporangial specimen; deposited in CNUK, Herbarium of Chungnam National University, Daejeon, Korea.

Type locality. Donggori, Wando, Korea (34 $19^{\prime} 57.32^{\prime \prime} \mathrm{N}$, $126^{\circ} 53^{\prime} 00.59^{\prime \prime} \mathrm{E}$ ).

Isotypes. CNU059009, CNU059010, CNU059011, and CNU059013 in CNUK, Korea.

Etymology. The specific epithet refers to the handshaped branches and branchlets. 


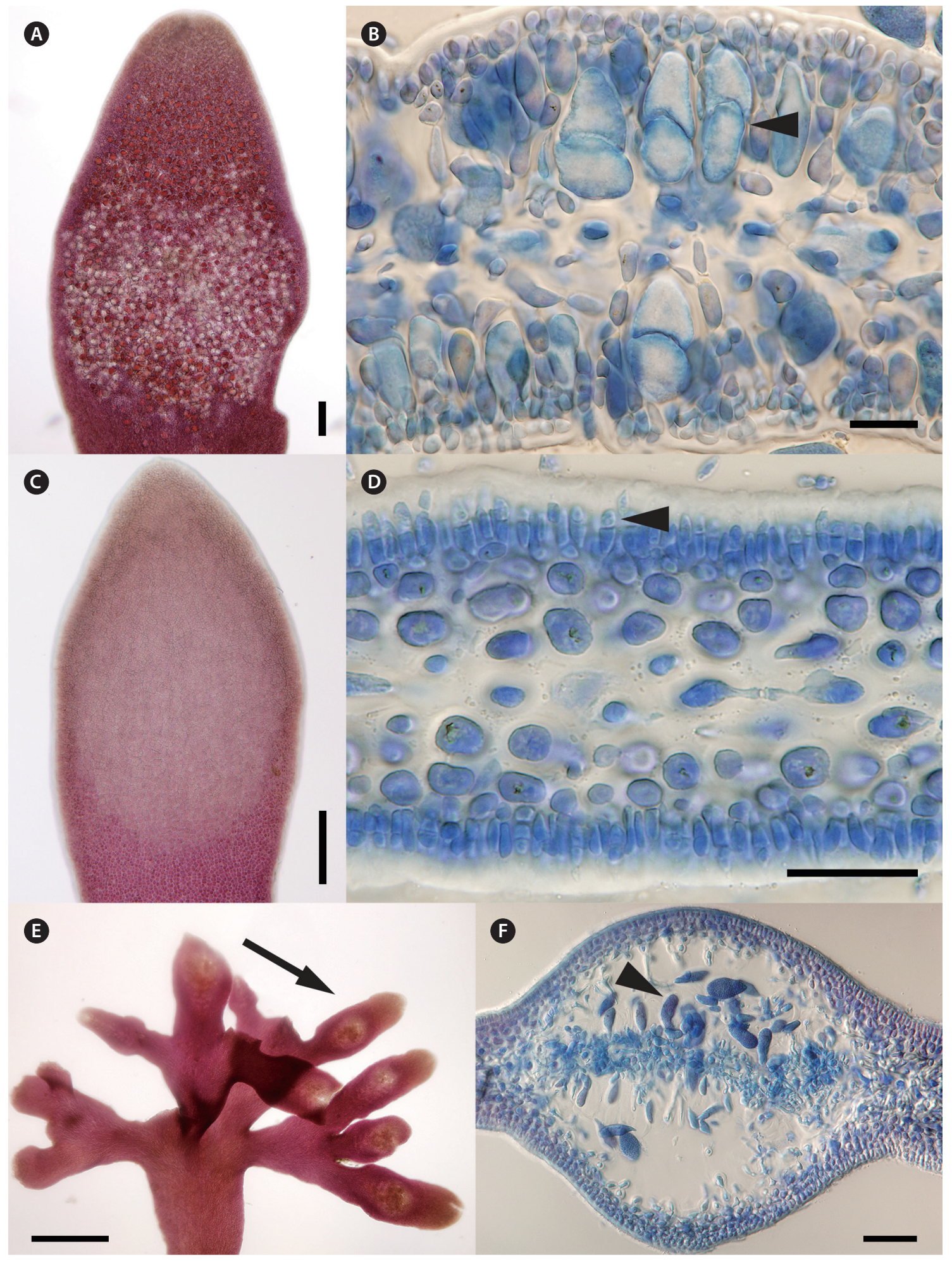

Fig. 2. Reproductive structures of Gelidium palmatum sp. nov. (A) Tetrasporangial stichidium-like branch (CNU059021). (B) Transverse section of tetrasporangial sorus with tetrasporangia (arrowhead) (CNU059024). (C) Thallus with spermatangial sorus (CNU059009). (D) Transverse section of spermatangial branchlet with spermatangia (arrowhead) (CNU059009). (E) Thallus bearing cystocarps (arrow) (CNU059007). (F) Transverse section of bilocular cystocarp with carpospores (arrowhead) (CNU059007). Scale bars represent: A \& C, $100 \mu \mathrm{m} ; \mathrm{B} \& \mathrm{D}, 20 \mu \mathrm{m} ; \mathrm{E}, 500 \mu \mathrm{m} ; \mathrm{F}, 50 \mu \mathrm{m}$. [Colour figure can be viewed at http://www.e-algae.org]. 


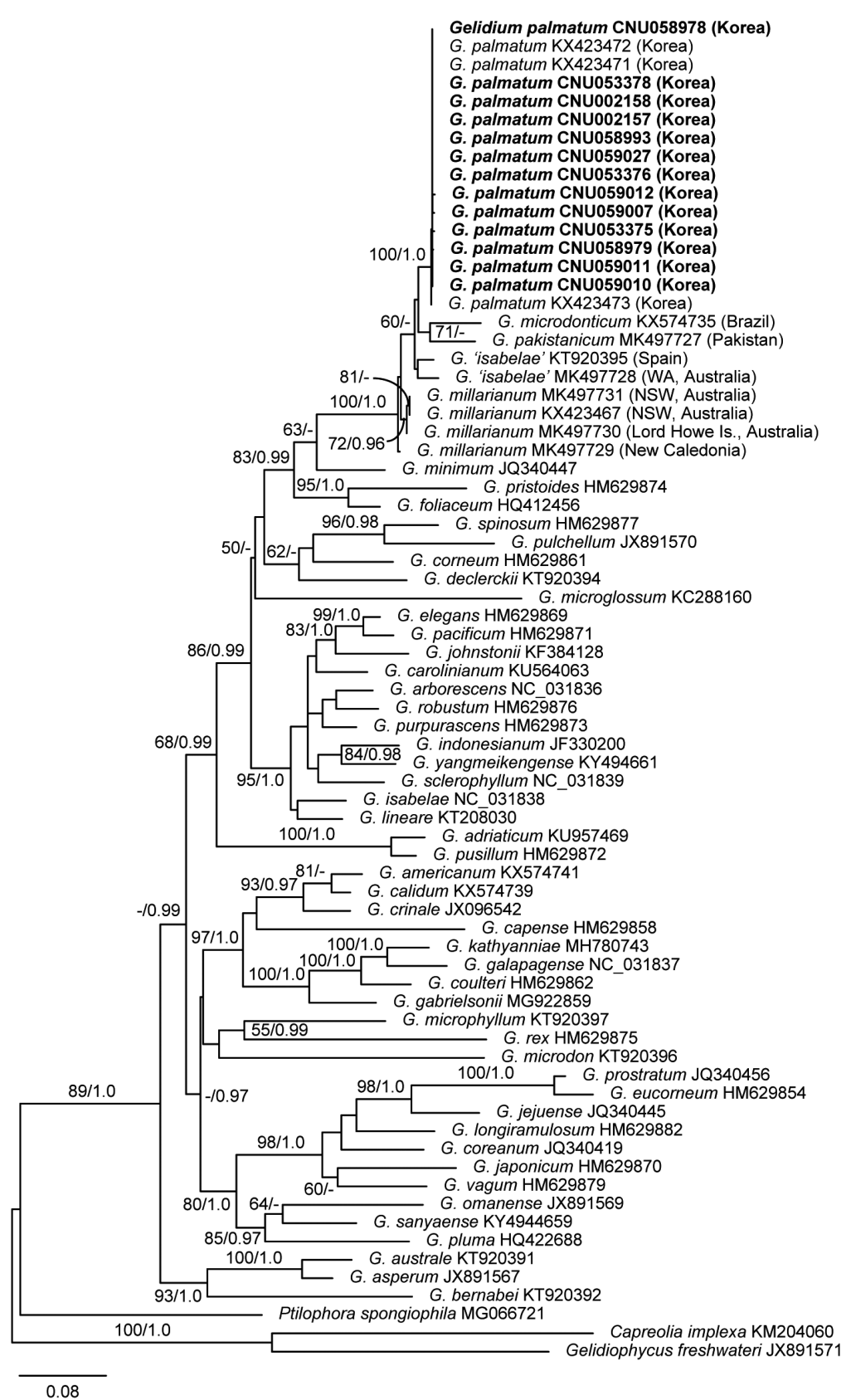

Fig. 3. Maximum likelihood (ML) phylogeny based on mitochondrial cox 1 sequences of the genus Gelidium. ML bootstrap values ( $\geq 50 \%)$ and Bayesian posterior probabilities $(\geq 0.90)$ are shown at branches. Dashes indicate values $<50$ or $<0.90$. Bold letters indicate newly generated sequences in this study.

DNA sequences of type specimens. For the holotype, MN784142 (cox1) and MN784151 ( $r b c \mathrm{~L})$; for isotypes, MN784140 and MN784141 (cox1), and MN784150 (rbcL).

Additional herbarium specimens observed. CNU053375, CNU053376 (Sorokdo, Goheung, Korea; Mar 26, 2010); CNU059007, CNU059008, CNU059021, CNU059022, CNU059024, CNU059027 (Donggori, Wando, Korea; Jul 14, 2014); CNU058978, CNU058979, CNU058993 (My- eongsasipri, Wando, Korea; Jul 13, 2014); CNU002157, CNU002158 (Munseom, Jeju Island, Korea; May 16, 2011); CNU053378 (Pyeongdae, Jeju Island, Korea; Mar 29, 2010); CNU053479 (Doduri, Jeju Island, Korea; Jun 17, 2008); CNU053379, CNU054668 (Geumneung, Jeju Island, Korea; Mar 30, 2010); CNU052132 (Gwideokri, Jeju Island, Korea; Oct 19, 2007).

Distribution and habitat. This species was confirmed 


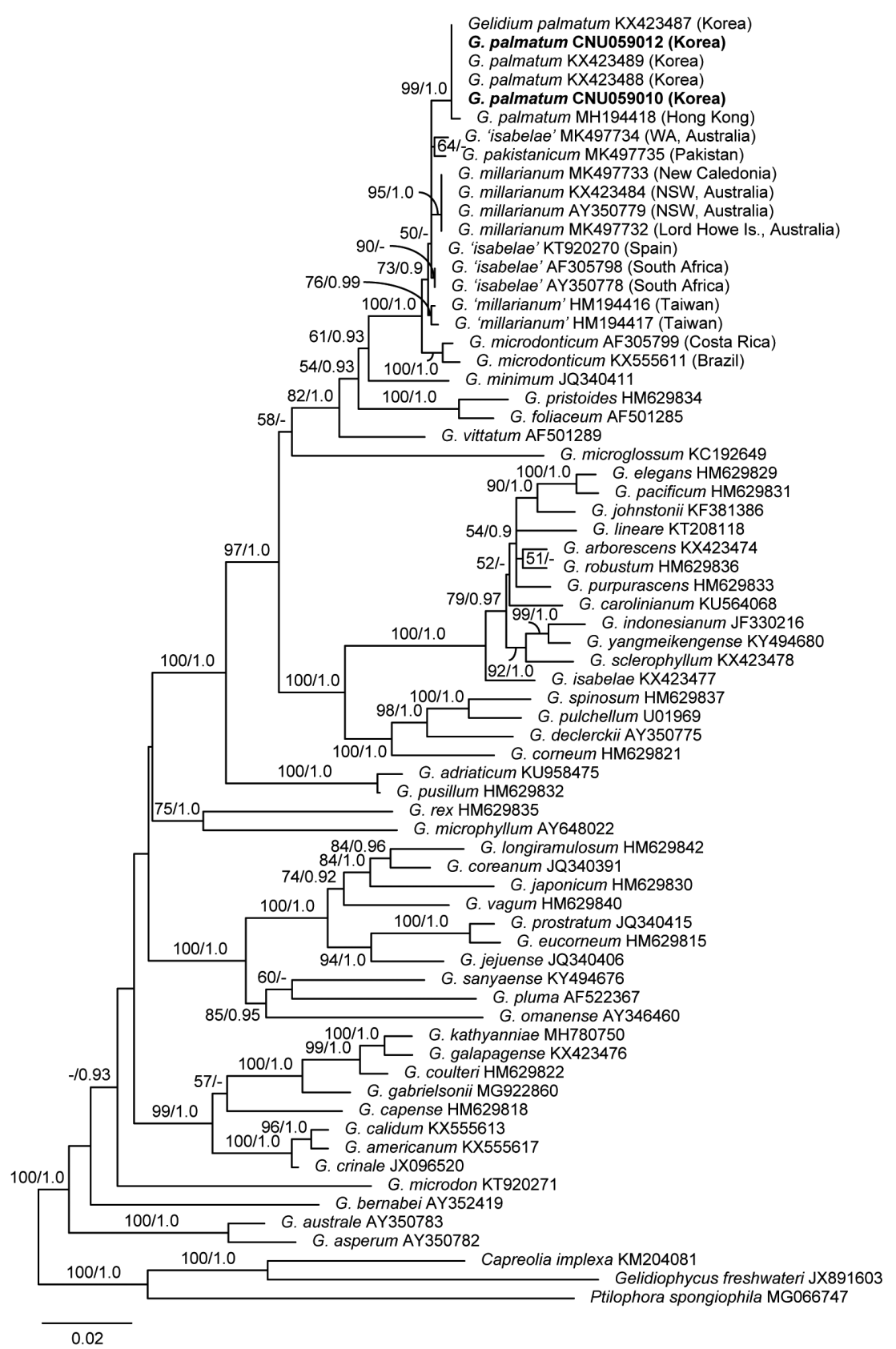

Fig. 4. Maximum likelihood (ML) phylogeny based on plastid $r b c L$ sequences of the genus Gelidium. ML bootstrap values ( $\geq 50 \%$ ) and Bayesian posterior probabilities $(\geq 0.90)$ are shown at branches. Dashes indicate values $<50$ or $<0.90$. Bold letters indicate newly generated sequences in this study.

on the southern coast (Goheung and Wando), and on Jeju Island, Korea. Its range extends to Stanley Bay, Hong Kong, where specimens were identified with sequence by Lin et al. (2018). It grows on upper intertidal rocks and in shaded rocky crevices, forming short turfs often mixed with Gelidiophycus freshwateri and / or Caulacanthus okamurae Yamada in Korea (Fig. 1A).

\section{Phylogenetic analyses}

Fifteen sequences were generated in this study, 13 cox 1 and two $r b c \mathrm{~L}$. A total of $73 \operatorname{cox} 1$ sequences were aligned with 60 previously published sequences of Gelidium from GenBank including our three outgroups (Supplementary Table S1). The Korean taxon, which we describe here as Gelidium palmatum sp. nov., was distinct from 
other species in the genus (Fig. 3). G. palmatum formed a fully supported clade with G. microdonticum, G. millarianum, G. pakistanicum, G. 'isabelae' from Spain and G. 'isabelae' from Western Australia (100\% ML, 1.0 BPP). The intraspecific divergences of G. palmatum were up to $0.4 \%$. G. palmatum was distinct enough to be segregated from other species of Gelidium; pairwise divergences of G. palmatum were $2.7-3.2 \%$ with G. millarianum, 4.8$5.0 \%$ with G. pakistanicum, $5.1-5.4 \%$ with G. microdonticum, 2.6-3.5\% with G. 'isabelae' from Spain, and 3.5-3.7\% with $G$. 'isabelae' from Western Australia.

The $r b c$ L phylogeny (Fig. 4) confirmed the strong monophyly of the genus Gelidium (100\% ML, 1.0 BPP). Five $r b c \mathrm{~L}$ sequences from Korean Gelidium palmatum formed a distinct clade that also contained G. 'millarianum' from Hong Kong (100\% ML, 1.0 BPP). G. palmatum formed a strongly supported clade with G. microdonticum, G. millarianum, G. pakistanicum, G. 'isabelae' from Western Australia, $G$. 'isabelae' from South Africa, $G$. 'isabelae' from Spain, and G. 'millarianum' from Taiwan (99\% ML, 1.0 BPP). The intraspecific divergence between specimens from Korea and Hong Kong was $0.2 \%$. Interspecific divergences between G. palmatum and the other species in the G. millarianum complex ranged from $0.4 \%$ (vs. G. 'isabelae' from Spain) to $0.9 \%$ (vs. G. millarianum).

\section{DISCUSSION}

Our analyses of mitochondrial $c o x 1$ and plastid $r b c \mathrm{~L}$ sequences, with morphological observations, clearly revealed the occurrence of a new species, G. palmatum from Korea. Gelidium palmatum is characterized by a combination of the following features: small size (about $0.7 \mathrm{~cm}$ high), compressed to lanceolate erect axes, irregularly digitate or palmate branches, rhizines abundant in the medulla, tetrasporangial sori without sterile margins, and rounded bilocular cystocarps born subapically on palmate to digitate branches. Phylogenetic analyses of both $r b c \mathrm{~L}$ and coxl sequences consistently demonstrated a marked difference between G. palmatum and other species in the genus. Gelidium palmatum occurs in Korea and Hong Kong, the latter being based on a $r b c \mathrm{~L}$ sequence in GenBank. However, without molecular analysis, one should hesitate to identify G. palmatum from other countries. Our results support the proposal of Boo et al. (2016a) that reports of G. galapagense and G. isabelae from sites outside the Galápagos Islands are the result of misidentifications of other species. Additional collections and analyses will probably extend the known distri- bution of G. palmatum to other sites in East Asia.

G. palmatum is well segregated from the G. millarianum species complex by pairwise divergences of cox 1 (2.6-5.0\%) and $r b c \mathrm{~L}$ (0.4-0.9\%). These values are similar to those between closely related species of Gelidium (Freshwater et al. 2010, Boo et al. 2014, Freshwater and Shahnaz 2019). For example, $r b c \mathrm{~L}$ pairwise divergence, estimated from GenBank sequences, between G. linoides Kützing and G. tenuifolium Shimada, Horiguchi \& Masuda from Japan was $0.3 \%$ (Boo et al. 2014). The cox 1 divergences between related species are reported to be 2.7-5.4\% (Freshwater et al. 2010, Boo et al. 2014, Freshwater and Shahnaz 2019). Mitochondrial coxl sequence is a useful tool for identification of closely related species, because its sequence is more variable, with larger barcoding gaps, than the conserved $r b c \mathrm{~L}$, which is less informative (Freshwater et al. 2010, Boo et al. 2016b).

A comparison of G. palmatum with morphologically similar species is given in Table 1 . In practice, it is not easy to delimit small sized species of Gelidium by a few diagnostic characteristics, as many cryptic species (molecularly distinguishable but morphologically indistinguishable) have been revealed by recent molecular studies (Boo and Hughey 2019, Brunelli et al. 2019, Perrone et al. 2019). Boo et al. (2016a) reported that Korean G. galapagense, herein described as G. palmatum, having lanceolate tetrasporangial branches without sterile margins is different from G. millarianum having tetrasporangial branches with retuse tips and a sterile margin. Kim and Hwang (2015) recognized Korean G. isabelae on the basis of longitudinal striations on the surface of branches. However, increased sampling in the present study revealed that both of tetrasporangial stichidium and longitudinal striations are not key characters of $G$. palmatum. Instead, both tetrasporangial stichidia, arising on fan- or digitate tip of a branch with a short pedicel, and rhizines abundant in medulla are considered as key characteristics of G. palmatum. However, rather than a few diagnostic characteristics, a combination of several morphological characteristics is more practical for recognizing G. palmatum from other small sized species of Gelidium.

G. galapagense (type locality: Banks Bay, Isla Isabela, Galápagos Islands) is distinguished by stichidium-like tetrasporangial branches that are irregularly palmately or digitately expanded from a constricted base (Taylor 1945). The previous use of tetrasporangial characters for Korean G. 'galapagense' (Lee et al. 2005, Lee 2008) is unreliable. All sequences in GenBank and in our personal Gelidium sequence library (G. H. Boo, unpublished) re- 


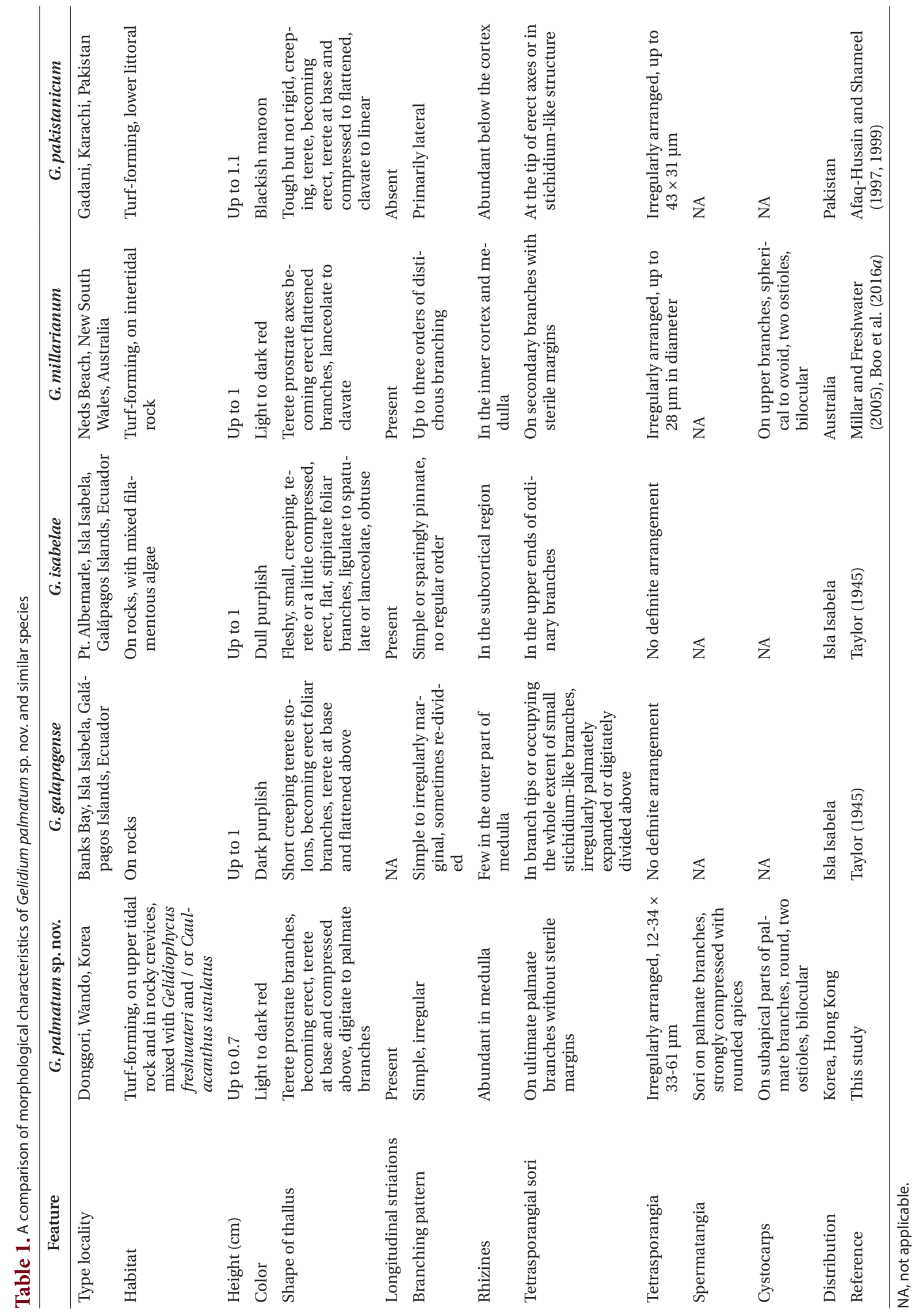


veal that G. galapagense is restricted to the Galápagos Islands.

G. isabelae (type locality: Pt. Albemarle, Isla Isabela, Galápagos Islands) has a creeping, firm thallus, simple or occasionally sparingly pinnate branches, and rhizines congested in the subcortical layer (Taylor 1945). Recently, Boo et al. (2016a) analyzed sequences from the type specimen of G. isabelae and concluded that it is endemic to the Galápagos Islands. Kim and Hwang (2015) reported $G$. 'isabelae' from Jeju Island based on the description of G. pusillum sensu Lee (1988) and G. pusillum var. pacificum sensu Lee and Kim (1995). They agreed with Millar and Freshwater (2005) and N'Yeurt and Payri (2010) that the visible decussate lines are a key character of $G$. 'isabelae' from Australia and French Polynesia. However, Boo et al. (2016a) identified the Australian plants as G. millarianum. Since the morphology and distribution of $G$. pusillum sensu Lee (1988) and G. pusillum var. pacificum sensu Lee and Kim (1995) are similar to our collections at five locations in Jeju Island, we here conclude that $G$. 'isabelae' from Jeju Island is G. palmatum.

A taxonomic revision is urgently needed for specimens identified as G. isabelae from French Polynesia, Japan, the Philippines, Spain, South Africa, and Western Australia (Silva et al. 1987, Yoshida 1998, Millar and Freshwater 2005, N'Yeurt and Payri 2010). Some of those specimens analyzed for cox 1 had a close relationship with G. millarianum (Boo et al. 2016a, Freshwater and Shahnaz 2019).

G. millarianum (type locality: Neds Beach, New South Wales, Australia) is up to $1 \mathrm{~cm}$ high and has flattened lanceolate to clavate main axes with three orders of distichous branches, rhizines abundant in both the subcortical layer and the medulla, and tetrasporangial sori with a sterile margin on secondary branches (Millar and Freshwater 2005, Boo et al. 2016a). G. millarianum occurs in New South Wales, Australia and New Caledonia. Lin et al. (2018) reported G. millarianum in Hong Kong and Taiwan based on $r b c \mathrm{~L}$ sequences. The specimen of $G$. millarianum from Hong Kong was nested in our G. palmatum clade and the rbcL pairwise divergence was $0.2 \%$, within the intraspecific-level variation reported in previous studies (Freshwater et al. 1995, 2010, Boo et al. 2013, 2014). The $r b c \mathrm{~L}$ divergences of Australian and Taiwanese specimens differed by $0.4-0.5 \%$. Based on the $r b c \mathrm{~L}$ phylogeny and pairwise divergences, the Taiwanese specimens may be re-examined morphologically and with additional analyses of mitochondrial coxl sequences.

G. pakistanicum (type locality: Gadani, Karachi, Pakistan) is small in size (up to $1 \mathrm{~cm}$ ) and main axes are terete, becoming compressed to flattened, lacking basal constrictions, and with primarily lateral branches (Afaq-Husain and Shameel 1997, 1999). Freshwater and Shahnaz (2019) noted that the $r b c L$ variation between $G$. pakistanicum and G. millarianum was lower than values generally considered as differentiating species.

In conclusion, our study reveals that the Korean reports of two Gelidium species with type localities in the Galápagos Islands result from misidentifications due to their small size and simple morphology. Our newly described G. palmatum, proposed for these misidentified specimens, commonly occurs on the southern coast of Korea and has been verified from Hong Kong. This study highlights the need for additional work on small, morphologically simple species in the agar-yielding genus Gelidium.

\section{ACKNOWLEDGEMENTS}

We are grateful to Dr. Sung Min Boo for providing helpful comments and suggestions, and Dr. Kathy Ann Miller for reading and valuable corrections in the first version of manuscript. This study was supported by Basic Science Research Program through the National Research Foundation of Korea (NRF) by the ministry of Education (2018R1A6A3A03012648) to GHB and the Efficient Securement of Marine Bioresources and Taxonomic Research (2020M00100) funded by the National Marine Biodiversity Institute of Korea (MABIK) to KMK.

\section{SUPPLEMENTARY MATERIALS}

Supplementary Table S1. Information on specimens included in molecular analyses. Bold indicates sequences generated in this study (https://e-algae.org).

\section{REFERENCES}

Afaq-Husain, S. \& Shameel, M. 1997. Observations on Gelidium pusillum (Stackh.) Le Jolis (Rhodophyta) from the coast of Pakistan. Pak. J. Bot. 29:185-190.

Afaq-Husain, S. \& Shameel, M. 1999. Further studies on Gelidium (Rhodophyta) from the coast of Pakistan. Pak. J. Bot. 31:371-382.

Boo, G. H. \& Hughey, J. R. 2019. Phylogenomics and multigene phylogenies decipher two new cryptic marine algae from California, Gelidium gabrielsonii and G. kathyanniae (Gelidiales, Rhodophyta). J. Phycol. 55:160-172. 
Boo, G. H., Hughey, J. R., Miller, K. A. \& Boo, S. M. 2016a. Mitogenomes from type specimens, a genotyping tool for morphologically simple species: ten genomes of agarproducing red algae. Sci. Rep. 6:35337.

Boo, G. H., Kim, K. M., Nelson, W. A., Riosmena-Rodriguez, R., Yoon, K. J. \& Boo, S. M. 2014. Taxonomy and distribution of selected species of the agarophyte genus Gelidium (Gelidiales, Rhodophyta). J. Appl. Phycol. 26:12431251.

Boo, G. H., Le Gall, L., Miller, K. A., Freshwater, D. W., Wernberg, T., Terada, R., Yoon, K. J. \& Boo, S. M. 2016b. A novel phylogeny of the Gelidiales (Rhodophyta) based on five genes including the nuclear CesA, with descriptions of Orthogonacladia gen. nov. and Orthogonacladiaceae fam. nov. Mol. Phylogenet. Evol. 101:359-372.

Boo, G. H., Park, J. K. \& Boo, S. M. 2013. Gelidiophycus (Rhodophyta: Gelidiales): a new genus of marine algae from East Asia. Taxon 62:1105-1116.

Brunelli, B., Jamas, M., Milstein, D., Boo, S. M. \& Fujii, M. T. 2019. Gelidium brasiliense sp. nov. (Gelidiales, Rhodophyta): a diminutive agarophyte from Brazil. J. Appl. Phycol. 31:951-958.

Callaway, E. 2015. Lap staple agar hit by seaweed shortage. Nature 528:171-172.

Chen, Y. W., Lee, H. V., Juan, J. C. \& Phang, S. -M. 2016. Production of new cellulose nanomaterial from red algae marine biomass Gelidium elegans. Carbohydr. Polym. 151:1210-1219.

Darriba, D., Taboada, G. L., Doallo, R. \& Posada, D. 2012. jModelTest 2: more models, new heuristics and parallel computing. Nat. Methods 9:772.

Freshwater, D. W., Fredericq, S. \& Hommersand, M. H. 1995. A molecular phylogeny of the Gelidiales (Rhodophyta) based on analysis of plastid $r b c \mathrm{~L}$ nucleotide sequences. J. Phycol. 31:616-632.

Freshwater, D. W. \& Rueness, J. 1994. Phylogenetic relationships of some European Gelidium (Gelidiales, Rhodophyta) species, based on $r b c \mathrm{~L}$ nucleotide sequence analysis. Phycologia 33:187-194.

Freshwater, D. W. \& Shahnaz, L. 2019. Phylogenetic relationships of Pakistan Gelidium (Gelidiales, Rhodophyta) species with recognition of Gelidium pakistanicum stat. nov. Bot. Mar. 62:141-147.

Freshwater, D. W., Tudor, K., O’Shaughnessy, K. \& Wysor, B. 2010. DNA barcoding in the red algal order Gelidiales: comparison of COI with $r b c \mathrm{~L}$ and verification of the "barcoding gap”. Cryptogam. Algol. 31:435-449.

Gavio, B. \& Fredericq, S. 2002. Grateloupia turuturu (Halymeniaceae, Rhodophyta) is the correct name of the nonnative species in the Atlantic known as Grateloupia do- ryphora. Eur. J. Phycol. 37:349-359.

Geraldino, P. J. L., Yang, E. C. \& Boo, S. M. 2006. Morphology and molecular phylogeny of Hypnea flexicaulis (Gigartinales, Rhodophyta) from Korea. Algae 21:417-423.

Guiry, M. D. \& Guiry, G. M. 2019. AlgaeBase. World-wide electronic publication, National University of Ireland, Galway. Available from: http://www.algaebase.org. Accessed Nov 22, 2019.

Kim, H. S. \& Hwang, I. K. 2015. Algal flora of Korea. Vol. 4, No. 10. Rhodophyta: Florideophyceae: Gelidiales, Gracilariales, Procamiales. Marine red algae. National Institute of Biological Resources, Incheon, 143 pp.

Kim, K. M. \& Boo, S. M. 2012. Phylogenetic relationships and distribution of Gelidium crinale and G. pusillum (Gelidiales, Rhodophyta) using $\operatorname{cox} 1$ and $r b c \mathrm{~L}$ sequences. Algae 27:83-94.

Kim, K. M., Hwang, I. K., Park, J. K. \& Boo, S. M. 2011. A new agarophyte species, Gelidium eucorneum sp. nov. (Gelidiales, Rhodophyta), based on molecular and morphological data. J. Phycol. 47:904-910.

Kim, K. M., Hwang, I. K., Yoon, H. S. \& Boo, S. M. 2012. Four novel Gelidium species (Gelidiales, Rhodophyta) discovered in Korea: G. coreanum, G. jejuensis, G. minimum and G. prostratum. Phycologia 51:461-474.

Kumar, S., Stecher, G. \& Tamura, K. 2016. MEGA7: molecular evolutionary genetics analysis version 7.0 for bigger datasets. Mol. Biol. Evol. 33:1870-1874.

Lee, H. B. 1994. Some species of Gelidium (Gelidiales, Rhodophyta) from Korea. In Abbott, I. A. (Ed.) Taxonomy of Economic Seaweeds with Reference to Some Pacific and Caribbean Species. Vol. IV. California Sea Grant College System, La Jolla, CA, pp. 67-79.

Lee, H. B. \& Kim, J. I. 1995. Notes on Gelidiales species from Korea. In Abbott, I. A. (Ed.) Taxonomy of Economic Seaweeds with Reference to Some Pacific Species. Vol. V. California Sea Grant College System, La Jolla, CA, pp. 161-174.

Lee, Y. P. 1988. Taxonomic studies on the Gelidiaceae (Rhodophyta) in Cheju Island. I. Some members of Gelidium. Korean J. Plant Taxon. 18:95-113.

Lee, Y. P. 2008. Marine algae of Jeju. Academic Press, Seoul, $477 \mathrm{pp}$.

Lee, Y., Kim, B. \& Kim, M. 2005. New records of marine algae from Jeju Island, Korea. J. Fish. Sci. Technol. 8:97-108.

Lin, S. -M., Fredericq, S. \& Hommersand, M. H. 2001. Systematics of the Delesseriaceae (Ceramiales, Rhodophyta) based on large subunit rDNA and $r b c \mathrm{~L}$ sequences, including the Phycodryoideae subfam. nov. J. Phycol. 37:881-899.

Lin, S. -M., Liu, L. -C., Guiry, M. D., Ang, P. Jr. \& Hsueh, H. 
-J. 2018. A reassessment of Gelidium divaricatum G. Martens (Gelidiaceae, Rhodophyta) from Hong Kong, including Gelidiophycus hongkongensis sp. nov. Phytotaxa 348:49-55.

Millar, A. J. K. \& Freshwater, D. W. 2005. Morphology and molecular phylogeny of the marine algal order Gelidiales (Rhodophyta) from New South Wales, including Lord Howe and Norfolk Islands. Aust. Syst. Bot. 18:215-263.

N’Yeurt, A. D. R. \& Payri, C. E. 2010. Marine algal flora of French Polynesia III. Rhodophyta, with additions to the Phaeophyceae and Chlorophyta. Cryptogam. Algol. 31:3-205

Perrone, C., Bottalico, A., Boo, G. H., Boo, S. M., Miller, K. A. \& Freshwater D. W. 2019. Gelidium adriaticum sp. nov. and Gelidium carolinianum sp. nov. (Gelidiales, Rhodophyta) from the Mediterranean Sea. Phycologia 58:359-373.

Ronquist, F., Teslenko, M., van Der Mark, P., Ayres, D. L., Darling, A., Höhna, S., Larget, B., Liu, L., Suchard, M. A. \& Huelsenbeck, J. P. 2012. MrBayes 3.2: efficient Bayesian phylogenetic inference and model choice across a large model space. Syst. Biol. 61:539-542.

Silva, P. C., Meñez, E. G. \& Moe, R. L. 1987. Catalog of the benthic marine algae of the Philippines. Smithson. Contrib. Mar. Sci. 27:1-179.

Sohn, C. H. \& Kang, J. W. 1978. The classification of family Gelidiaceae (Rhodophyta) in Korea. Publ. Inst. Mar. Sci. Nat. Fish. Univ. Busan 11:29-40.

Stamatakis, A. 2014. RAxML version 8: a tool for phylogenetic analysis and post-analysis of large phylogenies. Bioinformatics 30:1312-1313.

Taylor, W. R. 1945. Pacific marine algae of the Allan Hancock Expeditions to the Galapagos Islands. Allan Hancock Pac. Exped. 12:1-528.

Thiers, B. 2019. Continuously updated. Index Herbariorum: a global directory of public herbaria and associated staff. New York Botanical Garden's Virtual Herbarium. Available from: http://sweetgum.nybg.org/ih/. Accessed Nov 20, 2019.

Yoshida, T. 1998. Marine algae of Japan. Uchida Rokakuho Publ. Co., Tokyo, 1222 pp. 